Kusnilawati ${ }^{1}$

Moh Fauziddin ${ }^{2}$

Astuti $^{3}$

\title{
Meningkatkan Aspek Perkembangan Nilai Agama dan Moral Anak Usia Dini dengan Penerapan Metode Bercerita Tema Islami
}

\begin{abstract}
ABSTRAK
Penelitian ini bertujuan untuk mengetahui metode mercerita (Tema Islami) dapat meningkatkan Perkembangan Nilai Agama dan Moral Anak Usia 5-6 Tahun di POS PAUD Harapan Bunda Kecamatan Kampar Kiri Hilir. Jenis penelitian ini adalah penelitian tindakan kelas. Teknik pengumpulan data pengumpulan data dalam penelitian ini adalah observasi dan dokumentasi. Teknik analisis data yang digunakan dalam penelitian ini adalah teknik persentase. Hasil penelitian diperoleh kesimpulan terhadap hasil penelitian perkembangan nilai Agama dan Moral anak sudah berkembang sangat baik. Hasil analisis dapat dilihat peningkatan yang diperoleh dari setiap siklusnya. Peningkatan perkembangan nilai agama dan moral yang diperoleh dari sebelum dilakukannya tindakan ke siklus I peningkatan sebesar 28.7\%. Peningkatan perkembangan nilai agama dan moral dari siklus I ke siklus II sebesar 51.3\%, dan secara keseluruhan peningkatan Perkembangan Nilai Agama dan Moral dari data awal ke siklus II sebesar $94.81 \%$.
\end{abstract}

Kata Kunci : metode bercerita, tema islami, perkembangan nilai agama dan moral

\begin{abstract}
This study aims to determine the method of storytelling Islamic topics can improve the Development of Religious Values and Morals of Children Aged 5-6 Years in POS PAUD Harapan Bunda Kampar Kiri Downstream District. This type of research is classroom action research. Data collection techniques for collecting data in this study are observation and documentation. The data analysis technique used in this study is the percentage technique. The results of the study obtained conclusions on the results of research on the development of the value of Religion and Moral of children has developed very well. The results of the analysis can be seen the increase obtained from each cycle. Increased development of religious and moral values obtained from before the action taken to the first cycle increased by $28.7 \%$. The increase in the development of religious and moral values from cycle I to cycle II was $51.3 \%$, and overall the increase in the development of religious and moral values from the initial data to the second cycle was $94.81 \%$.
\end{abstract}

Keyword : storytelling Islamic topics, development of religious and moral values

\footnotetext{
1 Prodi PG-PAUD Universitas Pahlawan Tuanku Tambusai, Riau, Indonesia Email : kusnilawati.up@gmail.com

2 Prodi PG-PAUD Universitas Pahlawan Tuanku Tambusai, Riau, Indonesia

3 Prodi Pendidikan Matematika Universitas Pahlawan Tuanku Tambusai, Riau, Indonesia
} 


\section{PENDAHULUAN}

Pendidikan ditujukan untuk meningkatkan kualitas sumber daya manusia, sebagaimana dirumuskan dalam Tujuan Pendidikan Nasional dalam UU Sisdiknas Nomor 20 Tahun 2003, bahwa Pendidikan Nasional berfungsi mengembangkan kemampuan dan membentuk watak serta peradaban bangsa yang bermartabat dalam rangka mencerdaskan kehidupan bangsa, bertujuan untuk berkembangnya potensi peserta didik agar menjadi manusia yang beriman dan bertakwa kepada Tuhan Yang Maha Esa, berakhlak mulia, sehat, berilmu, cakap,kreatif, mandiri dan menjadi warga Negara yang demokratis serta bertanggung jawab. Oleh karena itu, pendidikan yang dilaksanakan harus memperhatikan pertumbuhan dan perkembangan anak sesuai dengan usianya.

Dalam proses pertumbuhan maupun perkembangan anak dalam kenyataannya adanya beberapa faktor yang mempengaruhinya. Baik dalam proses pertumbuhan dan biologisnya ataupun proses perkembangan (psikisnya) dari seorang anak.Memang tidak ada resep yang pasti untuk mendidik anak; karena perkembangan anak dipengaruhi oleh beberapa faktor yang kait mengkait. Anak akan memproses setiap peristiwa dari sudut pandangnya sendiri sehingga situasi tertentu akan berbeda pengaruhnya, tergantung anaknya. Termasuk dalam mengembangkan perilaku moral.

Melatih perilaku moral anak harus dilakukan sedini mungkin. Jika anak diberi kesempatan, ia akan punya konsep diri yang positif. Moral juga berarti mengajarkan tanggung jawab pada anak dan mengembangkan pula kebiasaan-kebiasaan baik yang positif. Hal ini akan terbawa sampai ia dewasa nanti.

Cara-cara yang sering dilakukan oleh orang tua atau guru untuk melatih perilaku moral anak pada saat anak masih berusia dini adalah dengan dimulai melakukan kebiasaan sederhana yaitu membiarkan anak mengerjakan pekerjaan ringan tanpa bantuan orang tua, seperti memakai baju sekolah atau sepatu sendiri.

Dengan adanya perilaku moral anak yang baik, maka seorang anak akan mampu menghadapi tantangan dalam kehidupan dan juga akan mampu mengadakan penyesuaian diri dengan lingkungannya dimana ia berada. Intinya, anak mempunyai perilaku moral yang baik, akan merasa percaya diri.

Anak dalam relasinya dengan orang tua, anak akan dengan sukarela berperilaku kurang baik pada orang tuanya. Fenomena yang sering terjadi antara lain berkaitan dengan perkembangan dari nilai praktis bagi usaha pengembangan perilaku moral pada anak. Kadangkala anak malas bangun pagi, acuh tak acuh, jorok, belum mau membantu orang tua dan, takut bergaul jika tidak bersama orang tua, hanya berani jika dekat dengan orang tua.Menghormati tamu, berteman dengan satu teman saja, suka memilih-milih karena teman bermain masih kurang.

Berdasarkan pengalaman dan pengamatan penulis di lapangan ditemukannya gejala-gejala seperti: 1) Adanya sebagian anak tidak mematuhi peraturan guru, hal ini terlihat bahwa anak Paud tidak mau bersalaman jika bertemu dengan orang yang lebih tua, dan anak tidak mau berbagai makanan pada teman-temannya, 2) Anak cenderung tidak bisa duduk makan dengan tenang, 3) Anak cenderung tidak mau menghargai temannya. Hal ini terlihat bahwa anak memaksa minta mainan teman dan anak mamaksa meminta makanan teman kalau tidak diberikan mengatakan tidak teman dan sebagainya.

Pendidikan nilai berperanan penting dalam upaya mewujudkan manusia Indonesia yang utuh.Pembinaan nilai sebagai bagian yang tak terpisahkan dari pendidikan dapat menjadi sarana ampuh dalam menangkal pengaruh-pengaruh negatif, baik pengaruh yang berasal dari dalam negeri maupun luar negeri. Sejalan dengan derap laju pembangunan dan laju perkembangan ilmu pengetahuan, teknologi dan seni (IPTEKS), serta arus reformasi sekarang ini, pembinaan nilai semakin dirasa penting 
sebagai salah satu alat pengendali bagi tercapainya tujuan pendidikan nasional secara utuh.

Dari beberapa permasalahan di atas, menunjukkan bahwa perkembangan nilai agama dan moral anak masih rendah, hal ini dikarenakan selama ini guru dalam memberikan pengajaran masih menggunakan metode ceramah.Untuk itu, perlu adanya media yang baru untuk meningkatkan perkembangan nilai agama dan moral anak. Salah satu media yang dapat diguna kan dalam meningkatkan perkembangan nilai agama dan moral anak adalah Metode bercerita.

Menurut Moeslichatoen (2004:157) bahwa metode bercerita merupakan salah satu pemberian pengalaman belajar bagi anak dengan membawakan cerita kepada anak secara lisan. Cerita yang dibawakanpun harus menarik dan mengundang perhatian tetapi tidak terlepas dari tujuan pembelajaran anak usia dini.

Berdasarkan latar belakang dan gejala di atas maka penulis tertarik untuk melakukan penelitian dengan judul "Meningkatkan Perkembangan Nilai Agama dan Moral Anak Usia 5-6 Tahun dengan Penerapan Metode Bercerita (Tema Islami) di POS PAUD Harapan Bunda Kecamatan Kampar Kiri Hilir".

Berdasarkan latar belakang masalah yang telah dipaparkan di atas, maka dapat dirumuskan masalahnya yaitu "Apakah Metode Bercerita (Tema Islami) dapat meningkatkan Perkembangan Nilai Agama dan Moral Anak Usia 5-6 Tahun di POS PAUD Harapan Bunda Kecamatan Kampar Kiri Hilir?"

Sesuai dengan latar belakang dan perumusan masalahnya, maka penelitian ini bertujuan untuk mengetahui Metode Bercerita (Tema Islami) dapat meningkatkan Perkembangan Nilai Agama dan Moral Anak Usia 5-6 Tahun di POS PAUD Harapan Bunda Kecamatan Kampar Kiri Hilir.

\section{KAJIAN TEORI}

Henry (2001:6.5) menyatakan bahwa bercerita dapat diartikan menuturkan sesuatu hal misalnya terjadinya sesuatu, perbuatan, kejadian yang sesungguhnya maupun yang rekaanatau lakon yang diwujudkan dalam gambar. Bercerita adalah suatu kegiatan yang dilakukan seseorang untuk menyampaikan suatu pesan, informasi atau sebuah dongeng belaka, yang bisa dilakukan secara lisan atau tertulis (Winda, dkk, 2008:5.3).

Sementara itu, istilah cerita anak menurut Santosa, dkk (2006:8.3), mengatakan bahwa istilah cerita anak merupakan istilah yang umum untuk menyebut sastra anak yang semata-mata bergenre prosa, seperti dongeng, legenda, mite yang diolah kembali menjadi cerita anak dan tidak termasuk jenis puisi anak atau drama anak. Sedangkan istilah bacaan anak lebih menekankan pada media tertulis, bahasa tulis dan bukan bahasa lisan.

Metode bercerita adalah cara bertutur kata menyampaikan cerita atau memberikan penerangan pada orang lain secara lisan. Oleh sebab itu, tujuan metode bercerita adalah melatih daya tangkap anak, melatih daya pikir, melatih daya kosentrasi, membantu perkembangan fantasi/imajinasi anak, menciptakan suasana yang menyenangkan dan akrab di dalam kelompok (Depdikbud, 1998: 15).

Metode bercerita adalah suatu cara penanaman nilai-nilai kepada anak dengan menggunakan kepribadian tokoh-tokoh melalui penuturan hikayat, legenda, dongeng dan sejarah lokal. Metode ini dapat digunakan untuk membantu penghayatan nilai dan moral serta pembentukan sikap (Aqib, 2010:99).

Menurut Moeslichatoen (2004:157) bahwa metode bercerita merupakan salah satu pemberian pengalaman belajar bagi anak dengan membawakan cerita kepada anak secara lisan. Cerita yang dibawakanpun harus menarik dan mengundang perhatian tetapi tidak terlepas dari tujuan pembelajaran anak usia dini. 
Berdasarkan beberapa teori di atas, dapat disimpulkan bahwa metode bercerita adalah salahsatu strategi pembelajaran dimana penyampaiannya melalui tutur kata secara lisandengan menceritakan kisah atau suatu peristiwa dan informasi tanpameninggalkan tujuan dari pembelajaran tersebut.

Dalam pelaksanaan suatu metode pembelajaran tentunya memiliki langkahlangkah tertentu yang menjadi ciri khas atau karakteristik metode itu sendiri. Begitu juga dengan kegiatan bercerita. Bachtiar (2005:190) kegiatan rinci dalam pelaksaan kegiatan bercerita dapat dilakukan dengan berpedoman pada tahapan berikut.

1. Menyampaikan tujuan dan tema kegiatan bercerita kepada anak

2. Melakukan organisasi anak, terhadap posisi dan tempat duduk kegiatan yang dilakukan anak selama bercerita.

3. Mengatur bahan, alat dan media yang diperlukan dalam bercerita.

4. Membuka cerita: menggali pengalaman anak dan mengaitkannya dengan tema cerita dalam pembelajaran kegiatan ini dikenal dengan istilah apersepsi.

5. Melaksanakan cerita dengan pengembangan yang disesuaikan dengan kebutuhan belajar

6. Mengaktifkan anak dalam bercerita baik secara fisik, maupun emosional, misalnya: memberikan sejumlah pertanyaan yang dapat direspon langsung, memberikan stimulus agar mereka bergerak, melompat dan sebagainya.

7. Mencari untuk mendapatkan balikan (feedback) dari anak mengenai pemahaman pesan dan pelaksanaan program bercerita

8. Mengajak anak untuk menyimpulkan atau membuat ringkasan dari isi pesan cerita

\section{Nilai Agama dan Moral}

Nilai dan moral merupakan dua kata yang seringkali digunakan secara bersamaan.Dalam Kamus Besar Bahasa Indonesia karangan Poerwadarminta (2007: 801) dinyatakan bahwa nilai adalah harga, hal-hal yang penting atau berguna bagi kemanusiaan. Menurut Koyan (2000 :12), nilai adalah segala sesuatu yang berharga. Menurutnya ada dua nilai yaitu nilai ideal dan nilai aktual.Nilai ideal adalah nilai-nilai yang menjadi cita-cita setiap orang, sedangkan nilai aktual adalah nilai yang diekspresikan dalam kehidupan sehari-hari.

Yusuf (2006:132) menyatakan istilah moral berasal dari kata latin "mos" (moris), yang berarti adat istiadat, kebiasaan, peraturan/ nilai nilai atau tata cara kehidupan. Sedangkan moralitas merupakan kemauan untuk menerima dan melakukan peraturan, nilai-nilai atau prinsip-prinsip moral.Nilai-nilai moral itu seperti (a) seruan untuk berbuat baik kepada orang lain, memelihara ketertiban dan keamanan, memelihara kebersihan dan memelihara hak orang lain, dan (b) Larangan mencuri, berzina, membunuh, meminum minuman keras dan berjudi. Seseorang dapat dikatakan bermoral, apabila tingkah laku orang tersebut sesuai dengan nilai-nilai moral yang dijunjung tinggi oleh kelompok sosialnya.

Secara sederhana "moral" berarti tata cara, kebiasaan atau adat. Sujiono dan Nuraini (2005:2) mengemukakan bahwa moral adalah kesesuaian sikap dan perbuatan dengan norma atau hukum bathiniah, yakni apa yang dipandang sebagai kewajiban kita.

Agama merupakan suatu yang dimiliki oleh setiap individu (anak) melalui perpaduan antara potensi bawaan sejak lahir dengan pengaruh dari luar individu. Sedangkan menurut Permendiknas No 58 Tahun 2009 yang menyangkut tentang nilai-nilai agama dan moral adalah mengenai landasan filosofis dan religi Pendidikan dasar anak usia dini, pada dasarnya harus berdasarkan pada nilai-nilai filosofis dan religi

Aulad : Journal on Early Childhood, 2018, 1(1), 28 - 38 
yang dipegang oleh lingkungan yang berada disekitar anak dan agama yang dianutnya. Didalam Islam dikatakan bahwa "seorang anak terlahir dalam keadaan fitrah, orang tuanya yang membuat anaknya menjadi yahudi, nasrani, yahudi, dan majusi," maka bagainana kita bisa menjaga serta meningkatkan potensi kebaikan tersebut, hal itu tentu harus dilakukan sejak usia dini.

Pendidikan agama menekankan pada pemahaman tentang agama serta bagaimana agama diamalkan diaplikasikan dalam kehidupan sehari-hari.Penanaman nilai-nilai agama tersebut disesuaikan dengan tahapan perkembangan anak serta keunikan yang dimiliki oleh setiap anak. Islam mengajarkan nilai-nilai keislaman dengan cara pembiasaan ibadah, contohnya puasa, shalat lima waktu, dan lain-lain.

Pengertian nilai-nilai agama Islam adalah pertama, yang dimaksud nilai dalam Kamus Purwadarminta adalah: a). harga dalam arti taksiran, b). harga sesuatu, c). angka kepandaian, d). kadar, mutu, e). sifat-sifat atau hal-hal yang penting atau berguna bagi kemanusiaan (Daroeso, 2012).

Dari penjelasan diatas penulis dapat menyimpulkan bahwa penanaman nilai-nilai agama dan moral adalah suatu proses edukatif berupa kegiatan atau usaha yang dilakukan dengan sadar, terencana dan dapat dipertanggung jawabkan untuk memelihara, melatih, membimbing, mengarahkan, dan meningkatkan pengetahuan, kecakapan sosial, dan praktek serta sikap keagamaan pada anak. (aqidah, tauhid, ibadah dan akhlak) yang selanjutnya dapat mengamalkan dalam kehidupan sehari-hari.

Dalam Permen 58 Tahun 2009 dikemukakan, moral termasuk dalam lingkup perkembangan nilai-nilai Agama dan Moral. Beberapa perilaku yang berkaitan dengan perilaku moral anak usia $5-6$ tahun, seperti:

1. Mengenal agama yang dianut.

2. Membiasakan diri beribadah.

3. Memahami perilaku mulia (jujur,penolong, sopan, hormat, dsb).

4. Membedakan perilaku baik dan buruk.

5. Mengenal ritual dan hari besaragama.

6. Menghormati agama orang lain.

\section{METODE PENELITIAN}

Penelitian ini dilakukan di POS PAUD Harapan Bunda Kecamatan Kampar Kiri Hilir. Waktu yang digunakan dalam penelitian ini selama 2 bulan terhitung sejak bulan Juni-Juli 2018. Dalam hal ini yang menjadi subjek penelitian adalah anak usia 5-6 tahun di POS PAUD Harapan Bunda Kecamatan Kampar Kiri Hilir yang berjumlah anak sebanyak 20 orang anak, terdiri dari 12 orang laki-laki dan 8 orang perempuan.

Jenis penelitian ini adalah penelitian tindakan kelas. PTK adalah salah satu cara yang strategis bagi guru untuk memperbaiki layanan kependidikan yang harus diselenggarakan dalam konteks pembelajaran di kelas dan peningkatan kualitas program sekolah secara keseluruhan (Yufiarti dan Chandrawati, 2009).

Penelitian ini dilakukan dalam dua siklus dan dua kali pertemuan. Adapun tahapantahapan yang dilalui dalam penelitian tindakan kelas, yaitu: Perencanaan/persiapan tindakan, Pelaksanaan tindakan, Observasi , Refleksi. Metode pengumpulan data penelitian yang telah dilakukan penulis adalah:observasi dan dokumentasi. Data yang diperoleh pada penelitian ini adalah data tentang perkembangan nilai agama dan moral, dianalisis dengan teknik analisis deskriptif. 


\section{HASIL PENELITIAN}

Berdasarkan pada permasalahan yang dihadapi oleh anak, Perkembangan Nilai Agama dan Moral Anak, penyebab munculnya permasalahan sebagaimana telah diuraikan pada bagian pendahuluan, dilakukan serangkaian tindakan untuk mengetahui permasalahan tersebut. Tindakan penelitian ini terdiri dari dua siklus. Dengan prosedur penelitian meliputi penyusunan rencana tindakan, pelaksanaan, pengamatan atau observasi dan refleksi, deskripsi masing-masing siklus dikemukakan berikut ini:

Pada kondisi awal Perkembangan Nilai Agama dan Moral Anak di POS PAUD Harapan Bunda Kecamatan Kampar Kiri Hilir masih rendah. Hal ini dapat dilihat dari kondisi anak yang belum mematuhi peraturan guru, hal ini terlihat bahwa anak Paud tidak mau bersalaman jika bertemu dengan orang yang lebih tua, dan anak tidak mau berbagai makanan pada teman-temannya.

Ketidakmampuan Perkembangan Nilai Agama dan Moral Anak sesuai dengan yang diinginkan disebabkan kurang kreatifnya guru dalam mengenalkan permainan yang berhubungan dengan Perkembangan Nilai Agama dan Moral Anak dan juga motivasi guru yang kurang dalam membuat kreativitas baru berupa permainan-permainan yang dapat membuat anak bersemangat dan senang dalam Perkembangan Nilai Agama dan Moral Anak.

Sebelum peneliti melaksanakan siklus I, peneliti melakukan pengamatan langsung terhadap kegiatan anak pada bulan Mei 2018. Dari observasi tersebut Perkembangan Nilai Agama dan Moral anak Pos POS PAUD Harapan Bunda Kecamatan Kampar Kiri Hilir berada pada kategori belum berkembang.

Skor yang dicapai, yaitu hanya mencapai angka 198 atau 39.58\% dengan kriteria belum berkembang, karena berada pada rentang 26-50\%. Berdasarkan hasil observasi tersebut menunjukkan bahwa Perkembangan Nilai Agama dan Moral anak masih rendah. Oleh karena itu, peneliti akan memperbaikinya melalui Metode Bercerita (Tema Islami).

\section{Aktivitas Guru}

Dari analisis data penelitian siklus menunjukkan bahwa aktivitas guru dalam meningkatkan Perkembangan Nilai Agama dan Moral anak melalui melalui Metode Bercerita (Tema Islami) mengalami peningkatan dari siklus pertama. Hal ini dapat dilihat pada setiap pertemuan mengalami peningkatan, pada siklus I sebesar $73.4 \%$ dan pada siklus II sebesar $81.0 \%$.

Agar lebih jelas hasil observasi aktivitas guru yang mengalami peningkatan mulai dari siklus I pertemuan pertama, siklus I pertemuan kedua, siklus II pertemuan pertama dan siklus II pertemuan kedua, dapat dilihat pada grafik berikut:

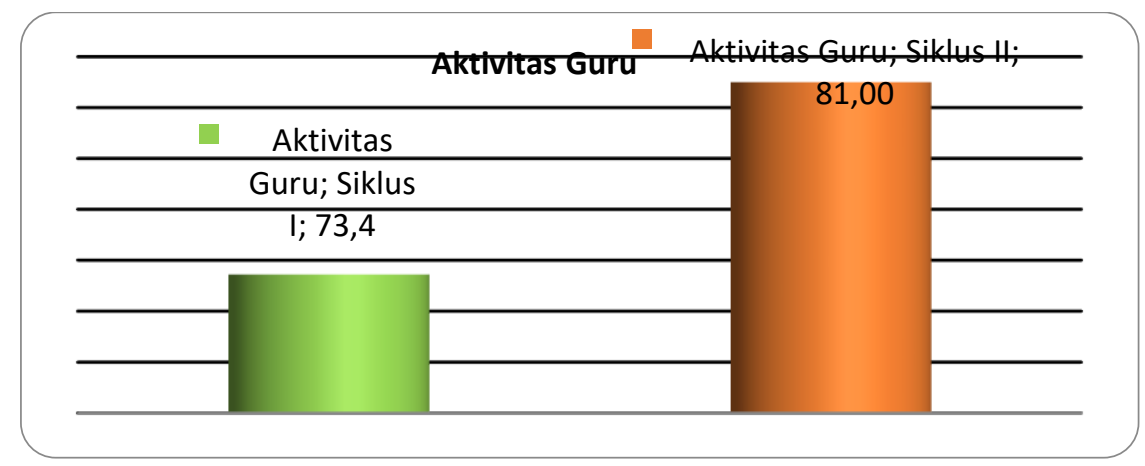

Gambar 4.1.Grafik Aktivitas Guru Pada siklus I dan Siklus II

Aulad : Journal on Early Childhood, 2018, 1(1), 28 - 38 


\section{Aktivitas Anak}

Peningkatan aktivitas guru pada setiap pertemuan, relevan dengan aktivitas anak.Secara umum aktivitas pembelajaran pada siklus II pertemuan kedua sudah dilakukan anak dengan baik hampir pada semua aktivitas

Nilai rata-rata yang diperoleh pada siklus I adalah $45.39 \%$ angka ini berada pada kategori cukup dan pada siklus II mengalami peningkatan yaitu sebesar $80.86 \%$ angka ini berada pada kategori baik. Hal ini terlihat dari setiap pertemuan aktifitas anak mengalami peningkatan.

Agar lebih jelas hasil observasi aktivitas anak yang mengalami peningkatan mulai dari pertemuan pertama, pertemuan kedua dan pertemuan ketiga, dapat dilihat pada grafik berikut:

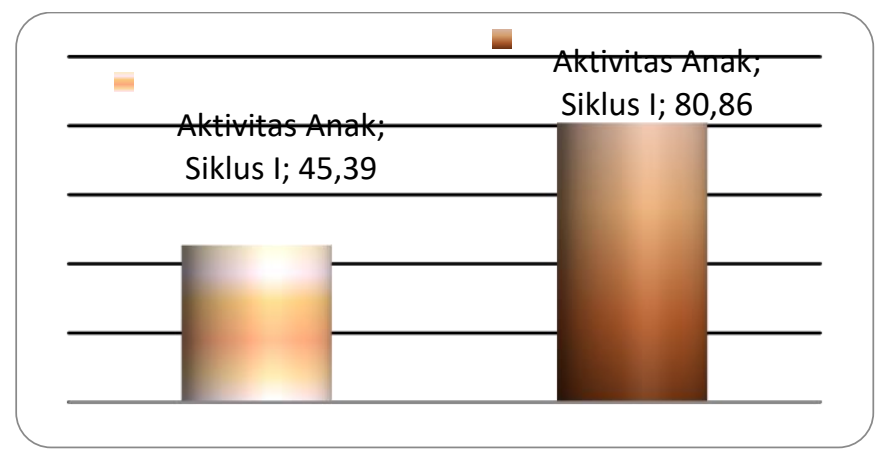

Gambar 4.2. Grafik Aktivitas Anak

Siklus I dan Siklus II

\section{Aspek Perkembangan Nilai Agama dan Moral Anak}

Rata-rata Perkembangan Nilai Agama dan Moral anak melalui melalui Metode Bercerita (Tema Islami) yang dilaksanakan di Pos POS PAUD Harapan Bunda Kecamatan Kampar Kiri Hilir dari siklus I pertemuan pertama ke siklus II pertemuan ketiga mengalami peningkatan.seperti yang terlihat pada tabel berikut ini.

Berdasarkan tabel di atas dapat dilihat bahwa setelah dirata-ratakan Perkembangan Nilai Agama dan Moral mengalami peningkatan dari data awal ke siklus I dan ke siklus II.Pada data awal diperoleh persentase 39.58\%, Pada siklus I diperoleh persentase $51.77 \%$, sedangkan pada siklus II diperoleh persentase sebesar $78.33 \%$.

Agar lebih jelas hasil Perkembangan Nilai Agama dan Moral anak melalui melalui Metode Bercerita (Tema Islami) mengalami peningkatan mulai dari data awal, Siklus I dan Siklus II, dapat dilihat pada grafik berikut: 


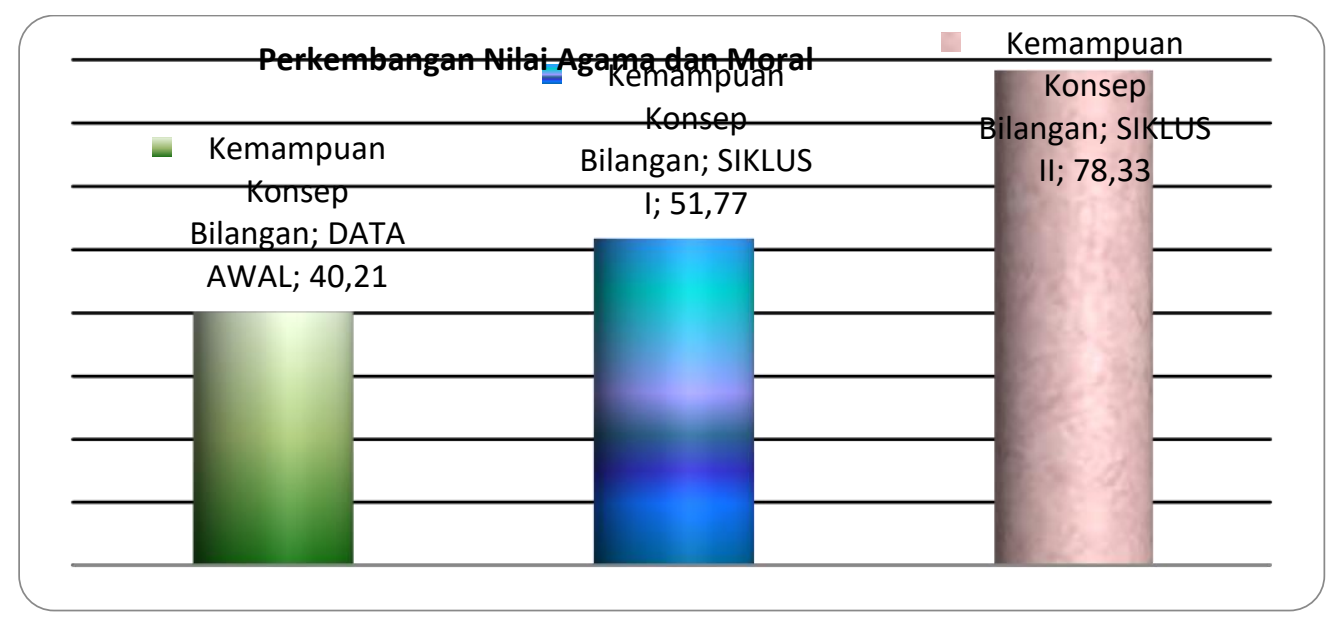

Gambar 4.3.Grafik Perkembangan Nilai Agama dan Moral Anak Pada Data Awal, siklus I, dan Siklus II

\section{PEMBAHASAN}

Berdasarkan hasil penelitian dapat diketahui bahwa melalui Metode Bercerita (Tema Islami) dapat meningkatkan Perkembangan Nilai Agama dan Moralanak usia 56 tahun di Pos POS PAUD Harapan Bunda Kecamatan Kampar Kiri Hilir. Hal ini sejalan dengan hasil penelitian Nony Amelia, dkk (2013) yang menunjukkan bahwa melalui pembiasaan menabung dapat meningkatkan aspek perkembangan nilai agama dan moral anak usia 5-6 tahun TK Al-Ikhlas Ketapang.

Nilai dan moral merupakan dua kata yang seringkali digunakan secara bersamaan.Dalam Kamus Besar Bahasa Indonesia karangan Poerwadarminta (2007: 801) dinyatakan bahwa nilai adalah harga, hal-hal yang penting atau berguna bagi kemanusiaan. Menurut Koyan (2000 :12), nilai adalah segala sesuatu yang berharga. Menurutnya ada dua nilai yaitu nilai ideal dan nilai aktual.Nilai ideal adalah nilai-nilai yang menjadi cita-cita setiap orang, sedangkan nilai aktual adalah nilai yang diekspresikan dalam kehidupan sehari-hari.

Metode bercerita adalah suatu cara penanaman nilai-nilai kepada anak dengan menggunakan kepribadian tokoh-tokoh melalui penuturan hikayat, legenda, dongeng dan sejarah lokal. Metode ini dapat digunakan untuk membantu penghayatan nilai dan moral serta pembentukan sikap (Aqib, 2010:99).

Hasil penelitian selanjutnya menjelaskan bahwa pada siklus I dan siklus II menunjukkan bahwa melalui Metode Bercerita (Tema Islami) dapat meningkatkan Perkembangan Nilai Agama dan Moral anak usia 5-6 tahun di Pos POS PAUD Harapan Bunda Kecamatan Kampar Kiri Hilir. Peningkatan tersebut dapat dilihat dari hasil tugas pengamatan yang dilakukan oleh penulis dan guru terhadap aktivitas anak. Hal ini sejalan dengan hasil penelitian Denok Dwi Anggraini (2015) yang menunjukkan bahwa menunjukkan bahwa adanya peningkatan pengembangan nilai agama dan moral melalui metode bercerita, dapat dibuktikan rata-rata skor pengembangan nilai agama dan moral pra tindakan sebesar 33,47\%.

Berhasilnya penelitian ini tidak terlepas dari peran guru dalam mengelola Perkembangan Nilai Agama dan Moraldalam pembelajaran.Perkembangan Nilai Agama dan Moralyang didesain guru dengan menggunakan Metode Bercerita (Tema Islami) yang bernilai edukatif yaitu aktivitas-aktivitas untuk memperoleh kesenangan dalam

Aulad : Journal on Early Childhood, 2018, 1(1), 28 - 38 
proses memecahkan suatu masalah tanpa menjadi beban anak namun dalam mencapai tujuan sama yaitu mencapai tujuan pembelajaran. Guru mempunyai tanggung jawab untuk membimbing anak mengantarkan anak ke arah aktivitas perkembangan, sedangkan anak berusaha untuk mencapai tujuan dengan bimbingan guru, sehingga interaksi itu merupakan hubungan yang bermakna dan kreatif. Hal ini dapat dilihat pada setiap siklus mengalami peningkatan, pada siklus I diperoleh nilai rata-rata sebesar $51.77 \%$. Kondisi ini dianggap belum berhasil sehingga dilaksanakan penelitian lanjutan. Pada siklus II aktivitas guru meningkat menjadi $78.33 \%$ dengan kriteria baik.

Pada siklus II dilakukan perbaikan pembelajaran dengan tetap menggunakan metode bercerita, namun pada siklus II ini peneliti memperbaiki cara penyambapian metode bercerita kepada anak, dimana peneliti lebih memperhatikan apakah anak sudah paham atau mengerti dengan cerita yang dibawahkan dengan penyampaian guru terhadap metode bercerita sehingga anak akan merespon dan mengikuti jalur cerita tersebut supaya dapat memperoleh pemahaman mengenai cerita yang dibawakkan.

Berdasarkan hasil penelitian dan observasi yang dilakukan hingga siklus II, menunjukkan adanya peningkatan perkembangan moral anak, yang berarti metode bercerita berdampak positif terhadap peningkatan perkembangan moral anak. Temuan yang diperoleh dalam metode bercerita ini antara lain: 1) Melalui metode bercerita ini dapat menciptakan perilaku yang baik bagi anak. 2) Metode bercerita dapat meningkatkan perkembangan moral anak. Hal ini dapat dilihat dari meningkatnya persentase indikator perkembangan moral anak seperti memiliki perilaku percaya diri, menunjukkan rasa toleran, menunjukkan rasa empati, menghargai hasil karya orang lain, memiliki taat aturan.

Suatu kengiatan belajar yang menggunakan trategi bercerita ternyata dapat menganjarkan siswa untuk berempati.Tentu saja kelebihan ini dapat dengan mudah kita maklumin karena strategi bercerita sangat melibatkan perilaku anak.Metode bercerita pada pengajaran yang direncanakan secara baik, dapat menanamkan perilaku, dan khlak anak dalam bermasyarakat, menanamkan perilaku bertanggung jawab dalam segalah hal yang dikerjakan anak, menghargai pendapat orang lain, sabar mengantiri dalam menunggu giliran.

Moeslichateonr."Metode bercerita merupakan sala satu pemberian pengalaman pembelajaran bagi anak usia dini dengan membawa cerita kepada anak secara lisan".Fadillah "metode bercerita adalah metode yang mengisahkan suatu peristiwa atau kejadian kepada peserta didik.Kejadian atau peristiwa tersebut disampaikan kepada peserta didik melalui tutur kata, ungkapan dengan mimik wajah yang unik.

Berdasarkan dari hasil penelitian dan pembahasan dapat buktikan bahwa hipotesis yang mengatakan " Terdapat peningkatan Perkembangan Nilai Agama dan Moral anak usia 5-6 tahun melalui Metode Bercerita (Tema Islami) di Pos POS PAUD Harapan Bunda Kecamatan Kampar Kiri Hilir", dapat diterima.

\section{SIMPULAN}

Dari hasil penelitian tindakan kelas dan pembahasan seperti telah diuraikan diperoleh kesimpulan terhadap hasil penelitian ini yaitu: Perkembangan Nilai Agama dan Moralanak usia 5-6 tahun di Pos POS PAUD Harapan Bunda Kecamatan Kampar Kiri Hilir sebelum penerapan Metode Bercerita (Tema Islami) berkriteria Belum Berkembang artinya secara klasikal atau secara umum Perkembangan Nilai Agama dan Moral anak Belum Berkembang. Sesudah melalui Metode Bercerita (Tema Islami) pada siklus I terdiri dari dua kali pertemuan dan siklus II dilakukan sebanyak 2 kali pertemuan yang berkriteria baik artinya secara klasikal atau secara umum Perkembangan Nilai 
Agama dan Moral anak sudah berkembang sangat baik. Dalam pengujian hipotesis dapat dilihat peningkatan yang diperoleh dari setiap siklusnya. Dimana peningkatan Perkembangan Nilai Agama dan Moral yang diperoleh dari sebelum dilakukannya tindakan ke siklus I peningkatan sebesar $28.7 \%$. Sedangkan peningkatan Perkembangan Nilai Agama dan Moral dari siklus I ke siklus II sebesar 51.3\%, dan secara keseluruhan peningkatan Perkembangan Nilai Agama dan Moral dari data awal ke siklus II sebesar $94.81 \%$.

\section{DAFTAR PUSTAKA}

Augusta, 2012.Pengertian Anak Usia Dini dari http://infoini.com/pengertian Anak Usia Dini

Aisyah, Siti,dkk. 2010. Perkembangan Konsep Dasar Pengembangan Anak Usia Dini. Jakarta: UT

Arikunto, Suharsimi, 2010. Prosedur Penelitian: Suatu Pendekatan Praktek, Jakarta: Rineka Cipta

Arikunto, Suharsimi, 2006. Penelitian Tindakan Kelas, Jakarta: Rineka Cipta

Aqib, Zainal, 2010. Profesionalisme Guru dalam Pembelajaran. Surabaya: Cendikia

Aqib, Zainal, 2009. Penelitian Tindakan Kelas. Bandung: CV. Yrama Widya

Bachtiar. 2005. Perkembangan Kegiatan Bercerita di Taman Kanak-kanak dan Teknik dan Prosedurnya, Jakarta: Depdiknas

Daroeso, 2012.Dasar dan Konsep Pendidikan Moral Pancasila.Semarang: CV. Aneka Ilmu

Depdiknas. 2009. Peraturan Menteri Pendidikan Nasional Republik Indonesia No 58. 2009. Standar Pendidikan Anak Usia Dini. Jakarta: Departemen Pendidikan

Depdikbud, 1998. Kamus Besar Bahasa Indonesia, Jakarta: Balai Pustaka

Dhieni, Nurbiana. 2006. MetodePengembangan Bahasa. Jakarta:Universitas Terbuka

Denok Dwi Anggraini. 2015. Peningkatan Pengembangan Nilai Agama Dan Moral Melalui Metode Bercerita.Jurnal PAUD

Henry, Guntur Tarigan. 2001. Berbicara. Bandung: Angkasa

Kuntjo, 2010.Strategi Pembelajaran untuk Anak Usia Dini dari http://ebekunt.wordpress.com

Koyan.2000. Pendidikan Moral Pendekatan Lintas Budaya.Jakarta: Depdiknas

Mansur. 2005. Pendidikan Anak Usia Dini dalam Islam. Yogyakarta: UT

Moeslichatoen.2004. Metode Pengajaran di Taman Kanak-kanak.Jakarta: Asdi Mahasatya

Nony Amelia, dkk. 2013. Peningkatan Aspek Perkembangan Nilai Agama Dan Moral Anak Usia 5-6 tahun TK Al-Ikhlas Ketapang. Jurnal PAUD

Permendiknas. 2003. Undang-undang tentang Sistem Pendidikan Nasional. Jakarta

Poerwadarminta. 2007. Kamus Besar Bahasa Indonesia, Jakarta: Balai Pustaka

Rahman, Hibama S, 2002. Konsep Dasar Pendidikan Anak Usia Dini. Yogyakarta: Galah

Aulad : Journal on Early Childhood, 2018, 1(1), 28 - 38 
Santosa, Puji. 2006. Materi dan Pembelajaran Bahasa Indonesia. Jakarta: UT

Sudijono, Anas. 2010. Pengantar Statistik Pendidikan. Jakarta: Raja Grafindo Persada

Sujiono, Bambang dan Nuraini, Yuliani. 2005. Bermain Kreatif, Berbasis Kecerdasan Jamak. Jakarta: Indeks

Sugiyono. 2010. Metode Penelitian Pendidikan Pendekatan Kuantitatif, Kualitatif dan $R \& D$, Bandung: Alfabeta

Suryana, dkk; 1996.Pendidikan Agama Islam.Bandung: Tiga Mutiara

Winda Gunanti, dkk. 2008. Metode Pengembangan Perilaku dan Kemampuan Dasar Anak Usia Dini, Jakarta:UT

Yusuf, Syamsu. 2006. Psikologi Perkembangan Anak dan Remaja, Bandung: Remaja Rosdakaryaa

Yulianti, Dwi, 2010. Bermain Sambil Belajar Sains di Taman Kanak-kanak.Jakarta: PT. Indeks 